\title{
Contemplation on Jurisprudence Principles and Necessities of Sheikh Fazlollah Nouri's Legitimate Constitutional Theory
}

\author{
By Ali Mohammad Tarafdari*
}

The victory of Constitutional Revolution during Muzaffareddin Shah Qajar is considered as one of the biggest political-religious developments in Iranian contemporary history during which the Shiite Ulema (clergymen) by their serious involvement in this movement and acceptance of its leadership created a modern era of various views about the constitutional political structure through using the huge legacy of the Shiite political jurisprudence. Meanwhile, a group of these Ulema by bringing up the issue of legitimate constitution tried to present a new reading of the Shiite political thinking concerning the criteria of the legitimacy or non-legitimacy of the constitutional system. Sheikh Fazlollah Nouri is considered one of the most leading religious figures whose jurisprudential thinking regarding the Iranian constitutional movement has been reviewed and analyzed in this article historically and jurisprudentially. The main point/question in the article is that why and under what religious and historical necessities a group of the Ulema, particularly Sheikh Fazlollah Nouri, stood against the constitutional system and started to bring up the plan of Legitimate Constitutional Theory? The findings of this study show that the Legitimate Constitutional Theory was formed as a result of the Shia jurisprudential necessities and the historical conditions of that period, and that based on the Nouri's viewpoint analyzed in his main works, he in the position of religious authority and religious jurist believed he was defending the bases of Islamic religion, while the sources of proconstitutionalists have considered Nouri's defense of Islam as the result of his support for autocracy.

\section{Introduction}

The occurrence of Constitutional Revolution in Iran during late Qajar era and basically the emergence of the constitutional movement in Iran's neighboring countries and then in Iran is considered as one of the most important and huge events of the contemporary history which has left lasting and influential impacts on Iran's social, religious, and political conditions. In fact, with the victory of the Constitutional Revolution in 1906 by the constitutionalists, a new period of the political life of Iran and Iranians started with the aim of removing domestic autocracy and gaining independence from the outsiders' hegemony the kingpin of which was to create the constitutional system as well as to establish a national consultative assembly. At the same time, the massive participation of the Ulema (clergymen) in the movement's leadership and then the opposition of a group of

*Assistant Professor of History, National Library \& Archives of I.R. of Iran. 
them to this current brought about one of the most important events which led to the victory of the movement and the emergence of constitutionalism and legitimism currents. This trend has so far been noticed by many researchers of Iranian contemporary history, and accordingly serious extensive for and against positions towards Sheikh Fazlollah Nouri's views have been emerged among the researchers which are in fact considered a continuation of for and against positions of the works and publications of the Constitutional era. ${ }^{1}$

On the other hand, it is not possible to review the current of Constitutional Revolution and the reasons behind the emergence of the Legitimate Constitutional Theory without addressing the political, ideological and jurisprudential positions of a jurist like Sheikh Fazlollah Nouri, ${ }^{2}$ because in addition to being involved in all various stages of the constitutional history, he has been the founder of the Legitimate Constitutional Theory and has brought up the most important and basic jurisprudential challenges regarding the theoretical principles of constitutionalism. Moreover, in addressing the reasons for the emergence of the Legitimate Constitutional Theory by Sheikh Fazlollah Nouri, it should be noticed that he himself has been among the first proponents of the Constitutional Revolution, thus it is necessary to pay attention to Nouri's principles of jurisprudence and historical conditions in order to identify the other factors of his change of mind.

The main question in the article is that why and under what religious and historical necessities a group of the Ulema, particularly Sheikh Fazlollah Nouri, stood against the constitutional system and started to bring up the plan of Legitimate Constitutional Theory?

\section{Rereading the Formation of Legitimism Current in Constitutional Revolution}

With the victory of Iran's Constitutional Revolution as the first nationwide anti-autocratic movement of Iranians through the participation of the majority of different strata of Iranian society during the reign of Muzaffareddin Shah Qajar (Mordad 14, 1285/August 6, 1906), the ruling monarchial system in Iran turned into a new political system based on the sovereignty of parliament. The movement's aim and the ideals of the people and the leaders of this anti-autocratic move was that after the fall of the ruling autocratic system, the will of the representatives of people's strata was involved in running the country and the national sovereignty replaced the individual absolute authorities and decisions. But according to the sources of the constitutional history, a short time after the issuance of the constitutional order and the deployment of the constitutional system and with the appearance of modern non-religious and sometimes anti-

1. For samples of such stances and the old and new views, see Nazem al-Islam Kermani, The Awakening History of Iranians, vol. 2, ed. by Ali Akbar Saeedi Sirjani (Tehran: Bonyad-e Farhange Iran, 1970).

2. For viewing the Sheikh Fazlollah Nouri's leading jurisprudential status, see also Mohammad Hassan Khan Etemad al-Saltanah, Al-Ma'aser val-Asar, vol. 1, ed. by Iraj Afshar (Tehran: Asatir, 1984), 151; Mehdi Malekzadeh, The History of Iranian Constitutional Revolution, Vol. 6 (Tehran: Elmi, 1994), 1257; Mohammad Esmaeel Rezvani, Iranian Constitutional Revolution (Tehran: Jibi, 1977), 199. 
religious approaches of the new system, first grounds of differences between the Ulema and their followers were emerged. The differences broadened when the Constitution was being drafted and reached its climax during its formulation and the approval of the Constitution's Amendment. ${ }^{3}$

But before reviewing the reasons and grounds of emerging such differences, it should be mentioned that the old sources and pro-constitutional history researchers in search for and explaining about the reasons of appearing the difference and basically the reasons of the opposition of Nouri and his other sympathetic Ulema to constitutionalism have regarded his opposition as the result of linking with Mohammad Ali Shah Qajar's Court, competition between the Ulema, autocracy, secularism and the like without paying attention to Nouri's attitude to the principles of constitutionalism with those of Islamic religion and his standing on this attitude until death. ${ }^{4}$ However, in his works and writings, Nouri presented reasons which had been derived from his jurisprudential thinking ${ }^{5}$ and his defense from these reasons is indicative of his religious belief in their validity, and that is partly why he became ready to sacrifice life in the way of his thought. The main factor for the continuation of the inattention of the old and new supporters of constitutionalism to the foundationology ${ }^{6}$ of Sheikh Fazlollah Nouri's jurisprudential thinking should be searched in the one-sided historiography of this group, because basically in the historiography of the constitutional movement in which pro-constitutional currents and contemporary intellectuals play a major role, the constitutional movement has been widely introduced as a national and patriotic movement, and the opponents of movement have been considered merely as authoritarians and pro-autocracy. In fact, during historiography which emerged following the victory of the Constitutional Revolution, the proponents and supporters of the constitutionalism share the most, and its main face is the introduction of the constitutional movement as a national revolution. In other words, the historiography of the Constitutional Revolution has fundamentally anti-autocratic and patriotic face influenced by nationalism and other modern ideologies. Their opinion about the movement is that the liberal and patriotic people of Iran started to fight Qajar's dictatorial system for freedom and improvement of their country's situation under constitutionalism, and many of them attained martyrdom in the way toward the victory of the Constitutional Revolution and winning freedom for their home and compatriots, or suffered from imprisonment, torture and exile. In this historiography, the fighters, the dead and the constitutional leaders were the nationalists who not only

3. Gholamhossain Zargarinejad, The Treatises of Constitutionalism, vol. 1 (Tehran: Kavir, 2008), P. 19

4. For viewing examples of such analysis of old sources and the works of new proconstitutional researchers, see Nazem al-Islam Kermani, The Awakening History of Iranians, vol. 1, ed. Ali Akbar Saeedi Sirjani (Tehran: Bonyad-e Farhang-e Iran, 1967), 12, 236; Ahmad Kasravi, Iran' Constitutional History (Tehran: Amirkabir, 1994), 826; Mehdi Malekzadeh, The Life of Malek al- Motakallemin (Tehran: Elmi, 1946), 294; Mohammad Ebrahim Bastani Parizi, Freedom Effort (Tehran: Nouvin, 1957), 170.

5. As an example of Nouri's jurisprudential analysis about constitutionalism, see Sheikh Fazlollah Nouri, "The Treatise of the Constitutional Sanctity," in The Treatises of Constitutionalism: Vol.1, ed. Zargarinejad (Tehran: Kavir Publication, 2008), 259-273; Sheikh Fazlollah Nouri, the Treatise of Tazkerat al-Qafel and Ershad al-Jahel (Tehran: Stone Printing, n.d.).

6. This term is from the writer which stress on study of the root of thoughts or events. 
promoted the conceptions like nation and freedom in the Iranian political literature of that period but did not spare even their life and property for achieving these conceptions and defending the ideals considered as holy. In the constitutional historiography, the nationalism has widely overshadowed all of its components, analyses and events and is considered a basis for the final and true judgment about the events especially its figures in a way that the constitutional opponents or in other words the legitimists and their main leader Sheikh Fazlollah Nouri due to their inevitable accompaniment with Qajar rule or the autocratic front (according to the literature of this historiography) are introduced directly or indirectly as nonnational or sometimes as anti-national people who have stood against the nationalists and patriots, and are called as martyrs, patriots and liberal vis-à-vis the constitutionalists especially those who were killed in the way of the constitutional movement. $^{7}$ Furthermore, the literature of this kind of historiography is very vitriolic along with insult toward the opponents and enemies of the constitutional movement especially Sheikh Fazlollah, and despite the modification of this literature in recent decades, the kingpins of the constitutional historiography to which were referred, also shape to a large extent the main lines of the historical reviews of proponents of the Constitutional Revolution almost until today, and pro-constitutional historiographical sources continue to express disgust or condemn Sheikh Fazlollah Nouri more or less. ${ }^{8}$

So, despite the existence and presence of such approaches, it is necessary to identify Nouri's jurisprudential and intellectual principles and reread his own ideas in order to review the other reasons for bringing up the Legitimate Constitutional Theory on the side of Sheikh Fazlollah Nouri, and the formation of legitimism current. Because, as it was referred, with a brief contemplation on the legitimists' works especially those of its famous leader Sheikh Fazlollah Nouri, it can be found out clearly that the opposition of the legitimists to the constitutional system and their effort for establishing the legitimate constitutional system that is the common state of the king and Mujtahid (religious authority) and their negative perception from the main pillars of the constitutional system and their fear and animosity with the issues like "legislation", "Towkil" (substituent), "freedom" and "equality" and the like has deep-rooted in the special perception of Sheikh Fazlollah and his colleagues from Shariah and the Shiite political philosophy and the acceptance of the reign of Shiite kings during the Greater Absence of the $12^{\text {th }}$ Imam of the Shiites Imam Mahdi and has had no substantial relationship with the competition over power. And, it is just in this case that Sheikh Fazlollah's persistence, and his refusal to express remorse may be more understood and explained. Although the opposition and conflict of the legitimists especially Sheikh Fazlollah Nouri to the constitutional system and issuance of heresy and atheism Fatwa -a religious edictby the constitutionalists started after a period of his accompaniment with the

7. As an example of this one-sided historiographical approach of pro-constitutional sources, see Iqbal Yaqmaee, The Martyr of Freedom Path Seyed Jamal Va'ez Isfahni (Tehran: Tous, 1978).

8. For instance, see Mehdi Malekzadeh, The History of Iranian Constitutional Revolution, vol. 3 (Tehran: Elmi Publication, 1994), 477-478; Fereydoon Adamiyat, Freedom Thinking and the Introduction of Constitutional Movement (Tehran: Sokhan, 1961), 254-255; Janet Afary, the Iranian Constitutional Revolution (1906-1911), Persian transl. Reza Rezaee (Tehran: Bisotun, 2000), 69; Mashallah Ajoodani, The Iranian Constitution (Tehran: Akhtaran, 2004), 131. 
constitutional movement, and unlike some other opponents ${ }^{9}$ of the constitutional system, he delayed for some time to announce the life and property of the constitutionalists as lawful, finally he issued Fatwa against constitutionalism, terming it as Haram or religiously prohibited and anti-Islam:

"Undoubtedly, the constitutional law is against the religion of Islam and it is not possible to bring an Islamic country under the constitutional law unless Islam is set aside. So, if a Muslim tries to make the Muslims constitutionalists, this is a measure in line with the destruction of the religion and such person is atheist and must be punished." ${ }^{10}$

It is obvious that this frank opposition could not be without religious reasons and without paying attention to Shiite jurisprudential principles. According to the Fatwa of the constitutional sanctity, not only many Iranians across the country were considered as atheist, and Ayatollahs Tabatabaee and Behbahani and all proconstitutional Ulema were the same, but the three sources of emulation in the Iraqi holy sites and all of pro-constitutional Ulema and Mujtahedins of that area were also considered as atheist. Thus, it is natural that a Mujtahid like Sheikh Fazlollah Nouri who was an expert in jurisprudential principles and the famous disciple of Mirza Shirazi, ${ }^{11}$ could not issue the atheism Fatwa of the Sources of Emulation like Akhund Khorasani, Mazandarani, Mirza Khalil Tehrani, Tabatabaee, Naeeni, Sheikh Esmaeel Mahallati, Haj Molla Rasoul Kashani, Agha Nourollah Isfahani, Agha Najafi and so on, and call their life and property as lawful and their blood as waste without relying on Shariah and jurisprudential reasons. ${ }^{12}$

\section{The Ups and Downs of Nouri's Positions against the Constitutional Movement}

According to the sources of Iranian constitutional history, Nouri's hesitation and pessimism toward the constitutional thinking dates back to early times of the rise of the movement and the time when the horizon of the constitutional movement was not still very clear to a Mujtahid like Nouri, and the national and covert associations were being set up. According to a report by Nazem alIslam who was a constitutionalist and a staunch enemy of Sheikh Fazlollah Nouri, in a talk to Sheikh Fazlollah along with Majd al-Islam for getting his approval in order to protest to the exile of Mirza Mohammad Reza, Mujtahid Kermani, and the dismissal of Zafar al-Saltanah the Governor of Kerman, Sheikh speaks about the necessity of protecting the monarchial state after hearing Majd al-Islam's remarks ${ }^{13}$ and although the quotation of Sheikh's remarks by Kermani is a one-

9. For example, see Fereydoon Adamiyat, The Ideology of Constitutional Movement (Tehran: Payam, 1976), P. 259

10. Nouri, "The Treatise of Constitutional Sanctity," in the Treatises of Constitutionalism, vol. 1, ed. Gholam Hussain Zargarinejad (Kavir Publication, 2008), 27.

11. Mehdi Bamdad, The Profile of Iranian Statesmen in 12th 13th 14th Hijri Centuries, vol. 3 (Tehran: Zavvar, 1968), 96.

12. Zargarinejad, The Treatises of Constitutionalism, 2008, 23-25.

13. Kermani, The Awakening History of Iranians, vol. 1, 81-83. 
sided report and his genuine remarks cannot be found out, the same report shows the basic of Sheikh Fazlollah's opposition to the demand of constitutionalists has been the existence of the central government and providing order and security as well as countering with the influence of Western thinking for protecting Islamic beliefs.

The sources of constitutional history and constitutionalists have again stressed Nouri's non-involvement in the consequent events which led to the victory of the constitutionalists like the event of bastinadoing the sugar merchants ordered by Ala' al-Doleh and closing of Tehran's bazaar by the merchants and their gathering in Shah Mosque along with a group of Ulema and the public (Shawal 1323 AD/ December 1905), and then the immigration of the protesters to the holy shrine of Hazrat Abd al-Azim in Shahr-e Ray (south of Tehran) led by Ayatollahs Tabatabaee and Behbahani known as "The Lesser Immigration". ${ }^{14}$ But, when "The Greater Immigration" was shaped in Jamadi al-Awal 1324 AD (July 1906), Sheikh Fazlollah Nouri joined the emigrants two days after their move toward Qom either for making them to return or for going along with them and getting the approval of the constitutionalists. ${ }^{15}$ The immigration is considered a turning point in Sheikh Fazlollah Nouri's final and firm position on the current of constitutionalism, because during the constitutionalists' sit-in in Qom, talks took place between Ayatollah Tabatabaee, the leader of the constitutionalists and Sheikh Fazlollah Nouri during which Nouri candidly expressed his final judgment and jurisprudential viewpoint concerning the constitutional system in the position of a Mujtahid, stressing that after the initial agreement with the constitutionalism for the expediency of Islam and the people, I regard the current as against the Shariah and Islam due to its contradiction with the Shariah. ${ }^{16}$ His viewpoint was later discussed in detail in the Treatise of the Constitutional Sanctity. However, on the basis of the report of some statesmen of that period, a number of researchers believe that the majority of the legitimists including Sheikh Fazlollah due to broadness of the constitutional current never ruled out the basis of constitutionalism in their official positions and speeches until the beginning of the period of Mohammad Ali Shah's victory over the constitutionalists and the start of the period nicknamed "The Lesser Autocracy". ${ }^{17}$

As the order of constitutionalism was issued and following the Greater Immigration and a sit-in in the British embassy, the first measure of the constitutionalists was to draft a constitution. In this line, due to lack of domestic sources in this regard and in view of the fact that the idea of constitutionalism has been taken from the West, the constitutions of Europe especially Belgium were mostly used for drafting the constitution, after its formulation, it was signed by Muzaffareddin Shah on Zel-qadeh 14, 1324 AD (December 30, 1906). Following the death of Muzaffareddin Shah and Mohammad Ali Shah's coming to power

14. For more details about such events, see Kermani, Ibid, 91-100; Kasravi, The Constitutional History, 1994, 60-66.

15. See, Kermani, Ibid, 263-266; Kasravi, Irans' Constitutional History, 106-107.

16. For the details of these talks, see Mirza Nasrollah Khan Mostofi, The History of Iranian Revolution, vol. 1 (Tehran: the manuscript of Malek Library no.3819), 26-28.

17. See Zargarinejad, The Treatises of Constitutionalism, 2008, 32; Malak al-Shoa'ra Bahar, A Brief History of Political Parties, vol. 1 (Tehran: Amirkabir, 1982), 2. 
who was the enemy of the constitutionalism since he was a crown prince, ${ }^{18}$ the legitimists' public opposition to the Constitution appeared gradually. As the time of the formulation and final approval of the Constitution Amendment - in which issues like legislation, freedom and equality had been included publicly - got closer, the opposition appeared in the form of active positioning against the parliament and the constitutional system because the supporters of the legitimate constitutionalism considered such issues as a heresy in Shariah and atheism. At this time, Sheikh Fazlollah Nouri and his colleagues had focused more on not to let the Constitution Amendment to be approved. But since their efforts remained inconclusive due to the resistance of the constitutionalist Ulema especially the clear support of three Sources of Emulation in the Iraqi holy sites particularly Akhund Khorasani, they sought to concentrate their efforts on deleting some of the current articles and principles in the Amendment. The second principle of the Amendment was drafted in this line and with the proposal and insistence of Nouri and the letters he wrote to the Sources of Emulation in Iraq. Finally, it was added to the Amendment's draft with Khorasani's approval for endorsement in the parliament. ${ }^{19}$ After the Amendment's endorsement, however, Sheikh and his followers continued to oppose it because their proposed reforms in the Amendment approved also by Akhund $\operatorname{Khorasani}^{20}$ had not been endorsed completely, and led to numerous clashes between the constitutionalists and legitimists, and even the publication of Lavayeh newspaper by Sheikh Fazlollah Nouri $^{21}$ during which the constitutionalists tried to attribute Nouri and his colleagues' opposition to their dependence on Mohammad Ali Shah and being pressured by him. ${ }^{22}$ But the content of the Lavayeh foreshadows emphasis on defending Islam and support for the constitutionalism on the condition of observing Shariah:

"In the Name of God, the Most Compassionate, the Most Merciful; this paper is written for the religious brothers to know and understand that there is no worldly purpose at all. The aim is just to protect Islam from the deviations the atheists look for. First, the auspicious word "legitimate" should be added to the word "constitutional" at the beginning of the Constitution. Second, the bill of the Ulema's supervision should be added without any change and the board of supervisors should be determined only by Sources of Emulation whether they determine or being determined by their own lot and the article Hojjat al-Islam Akhund Khorasani asked the honorable parliament to be added to the Constitution. Third, the reforms in the

18. See Kermani, The Awakening History of Iranians, vol. 2, 65-66; Kasravi, Irans' Constitutional History, 1994, 201-204.

19. Zargarinejad, The Treatises of Constitutionalism, 2008, 35.

20. For viewing the reasons for Nouri's opposition in this regard, see Mohammad Torkaman, Treatises, communiqués, written materials, ... and Sheikh Fazlollah Nouri's newspapers, vol. 1 (Tehran: Rasa, 1983), 267-268.

21. Homa Rezvani (ed.) Agha Sheikh Fazlollah Nouri's Lavayeh (Tehran: Nashr-e Tarikh-e Iran, 1983).

22. In this regard, see Sheikh Mohammad Mardoukh Kordestani, Mardoukh History (Tehran: Karang, 2000), 494. 
articles should be according to Islamic Shariah and must be included in the Constitution without any change and conversion; God willing." ${ }^{23}$

On the other hand, the continuation of Mohammad Ali Shah's opposition to constitutionalism and the constitutionalists, and Russia's support for the Qajarid Shah for overthrowing the constitutional system finally led to a military coup against the parliament and the arrest and killing of some leaders of the constitutional movement and the closure of the parliament by Mohammad Ali Shah with the help of Russian Cossack forces on Jamadi al-Thani 23, 1326 (July $23,1908),{ }^{24}$ and naturally pro-constitution sources reported of Nouri's cooperation with Mohammad Ali Shah in the measure. ${ }^{25}$ The constitutionalists have called this period as "The Lesser Autocracy". But this period for the legitimists was the beginning of a new era to explain their ideas against constitutionalism largely and freer, stressing the principles of constitutionalism with Shariah through writing various treatises. On the other hand, when Mohammad Ali Shah bombarded the Majlis (parliament), the constitutionalists started a nationwide conflict to overthrow the Shah's monarchy a sharp edge of which had targeted the person of Sheikh Fazlollah Nouri. Finally, the leaders of the conflict could win over the Shah and seize Tehran on Jamadi al-Awal 24, 1327 (July 13, 1909) and hang Sheikh Fazlollah as the leader of the legitimists and on charges of defending autocracy on Rajab 13, 1327 (July 31, 1909). ${ }^{26}$ But the other reasons behind the execution as it is obvious from the last words Nouri said before the gallows, ${ }^{27}$ was his firm standing on its own ideas in defending Islamic values, and moreover, the execution as some researchers have said was a kind of showing power to the Ulema including those who were for or against the constitutionalism. ${ }^{28}$

The event of hanging Sheikh Fazlollah Nouri was so important, effective and crucial that the sources of the constitutional history and the researchers of this area including opponents and proponents of constitutionalism or Nouri have stressed its importance and greatness. Because a secular current for the first time succeeded in trying and executing a senior religious authority, and if we consider the power of the Ulema during Qajar era especially the Nasseri period and the incidents like Tobacco Movement, then the importance of Nouri's execution is doubled. Thus, in view of this significance, almost the majority of the sources and researchers of the constitutional history especially the proponents of the legitimate constitution have

23. Torkaman, Treatises, communiqués, written materials, ... and Sheikh Fazlollah Nouri's newspaper, 1983, 231-232.

24. Yahya Dowlatabadi, the Life of Yahya, vol. 2 (Tehran: Ferdowsi, 1982), 161-162; Kasravi, Iran's Constitutional History, 580-584; Bahar, Brief History of Iranian Political Parties, 2-3.

25. Mehdi Qoli Hedayat, Memories and Risks (Tehran: Zavvar, 1982), 161.

26. Tondar Kia, The Secret of Gallows, An analytical report on the resultant of Ayatollah Sheikh Fazlollah Nouri's joining to the Constitutional Movement (Tehran: Kitab-e Sobh, 2002), 56.

27. For seeing the Nouri's last words before the gallows, see Tondar Kia, The Secret of Gallows, an analytical report on the resultant of Ayatollah Sheikh Fazlollah Nouri's joining to the Constitutional Movement (Ketab-e Sobh Publication, 2002), 58.

28. Zargarinejad, The Treatises of Constitutionalism, vol. 1, 89. 
described Nouri's execution as a huge incident against Islam and Ulema and Islamist current. $^{29}$

\section{Explanation on Jurisprudential Principles and Necessities of Legitimate Constitutional Theory in the Works of Sheikh Fazlollah Nouri}

As it was discussed above, Sheikh Fazlollah Nouri criticized and rejected the constitutionalism in his statements and pamphlets since the appearance of the constitutional movement. But during the Lesser Autocracy, he particularly wrote two treatises -The Sanctity of Constitutionalism, and Tazkerat al-Qafel and Ershad al-Jahel-according to historical conditions of the society of that period, and started to explain about the Legitimate Constitutional Theory and the reasons for the contradiction of constitutionalism with Islamic bases by using the jurisprudential legacy of the Shiite world. Therefore, in view of the time of the two books' writing, they in fact cover the entire Nouri's historical and jurisprudential arguments against the constitutionalism. So, it is necessary to refer to them for better analyzing of his legitimate theory.

Among the two books, The Sanctity of Constitutionalism or answering the reason for the initial agreement with constitutionalism and later opposition to it, is a book in which the bases and reasons for being Haram of constitutionalism and the constitution has been discussed and explained. At the beginning of the book, it has been asked from Hojjat al-Islam Wal-moslemin Sheikh Fazlollah Nouri ${ }^{30}$ that after the entry of constitution to Iran whose people divided into three groups of the enthusiasts, deniers and skeptics, why did he first defend the constitutionalism and try to spread it and then suddenly expressed his opposition? Has this agreement and opposition been on the basis of religious reasons and religious necessities or other reasons have caused his final opposition? Following this introduction which in fact explains about the reason and necessity of writing the treatise, Sheikh Fazlollah after thanking God for defending Islam courageously explained about the religious reasons for the contradiction of constitutionalism with Islam. First, he has mentioned that the origin of the event is the Western materialistic thinking, calling the constitutional event as "New Sedition". ${ }^{31}$ The two points are very enlightened in analyzing the religious reasons for his disagreement; because first, using the word "sedition" which has a special meaning in religious and Islamic literature and is used about anti-Islamic organized conspiracies, represents the final interpretation and judgment of the speaker concerning the nature and root of the constitutional story, and second, relying on non-religious and even anti-religious origin (on the viewpoint of Nouri) for a movement like the constitutionalism causes a person committed to defending Islam against anti-religious and materialistic thinking to stand against such movement religiously and in a Jihad-

29. For seeing some of these ideas, see Javad Bahmani, The Tragedy of Century or Executing Sheikh Fazlollah Nouri, the Most Senior Religious Figure of Tehran in Public (Tehran: 1980); Mustafa Boroujerdi, The First Acclaimer of Legitimacy in Constitutional Injustice (Tehran, n.d.).

30. Nouri, the Treatise of the Sanctity of Constitutionalism, 257.

31. Ibid, 259 
like manner. In other words, Sheikh Fazlollah Nouri like many of his companions had the imagination of seeing the hands of various non-Islamic and even antiIslamic sects (on the viewpoint of Nouri) and minorities such as Babbitt and Bahia $^{132}$ in the constitutional movement, and because of this, as it could be seen in the continuation of reviewing the discussions of the treatise, although like many constitutionalist Ulema, he could also have compromised between equality, freedom of speech, press and so on with Islam, tried to introduce the basis of constitutionalism in complete contrast to Islamic laws and faith by emphasizing on the non-Islamic dimensions of the issues like legislation and equality, because he imagined the designers of such issues as enemies of Islamic community.

This is a key point for analyzing the reasons behind the deep and serious opposition of many Ulema and senior religious authorities like Sheikh Fazlollah Nouri to the constitutionalism, but it has been less noticed by the researchers and is seen almost in no pro-constitutional source or supporter. Meanwhile, if we pay more attention to the viewpoint of the oppositions to constitutionalism like Nouri, we realize that the fundamental reason for the opposition of legitimate Ulema to the constitutionalism was rooted in non-Islamic ideologies lied in the constitutional system such as nationalism and the natural backing of non-Islamic Babbitt and Bahia' sects. In other words, with the rise of nationalism thinking during the constitutional government, on one hand, the ruling monarchial system saw its interests and traditional rights especially its legitimacy in danger, and on the other hand, the backers the society's religious and traditional system, the Ulema who explained and executing the rights of the society's individuals as the members of an "Ummah" and according to religious criteria, stood against the symbols of the constitutional ideology. In fact, the most challenges and oppositions -whether by the Qajarid monarchial system or by the Ulema- to the constitutionalism both practically and theoretically lied in the symbols of the nationalism ideology which regarded all the people of a society as the individuals of a nation, and their land as a country not the Land of the Sultan, the Shadow of God, and was in favor of the rule of the nation under "National Rule". And this point caused almost the majority of pro-constitutional religious minorities and intellectual and practical campaigners stood against the traditional Ulema who were against the constitutionalism in order to set up and protect the movement. And because of this, the main part of the constitutionalists was attributed to religious sects and minorities especially Babbitt and Bahia', because the followers of various religions and faiths which were widely involved in religious-political campaigns against the Islamic rule, wanted religious freedom and the rule of a political system -if possible- more than any other groups. The British missionary, Napier Malcolm who was living in Iranian city of Yazd concurrent with the Constitutional Revolution refers to this point clearly and wrote that at present, the Bahia's more than any other group wanted nationwide religious freedom. ${ }^{33}$

Thus, in view of these facts, the reason for Nouri's opposition to the symbols of the constitutional system can be better analyzed in continuation of the

32. For seeing an example this kind of Nouri's reading of the constitutionalism, see Torkaman, Treatises, communiqués, written materials, ... and ... Sheikh Fazlollah Nouri's newspaper, 267.

33. Napier Malcolm, Five Years in a Persian Town (London: John Murray, 1907), 52. 
discussions of the treatise of the Sanctity of Constitutionalism in a way that in stressing the issue, he says in the initial discussions of his treatise: "When the purpose was started to be carried out, I saw a group of people who were always aware of some deviations, were involved in it". ${ }^{34}$ Then, he considers representation and the validity of the majority of the votes as the most definite issues which is incompatible with Islamic Shariah. Then, for showing his emphasis on being Islamic of the article of the Constitution or as he says "that damned order", Nouri points to his efforts for including "the article of the Mujtahedins' supervision in every period" in the Constitution's Amendment and the constitutionalists' disagreement with it due to their animosity with Islam. But the most important discussion of the treatise is Sheikh Fazlollah Nouri's detailed involvement in the religious reasons for being Haram of the constitutionalism. Then, he also refers to the articles of the Constitution's Amendment or as he says "letter of deviation", one of the articles of which is the equality between all the country's people, the one which is in contradiction with the Islamic Shariah from Nouri's point of view. And in his response to the insistence of the constitutionalists on the importance of the article as one of the fundamental bases of the constitutionalism, he considers as impossible the existence of the equality decree in Islam, because according to his jurisprudential belief and on the basis of the edicts of the Shiite jurisprudence, there are various basic differences between "adolescent and non-adolescent, sane and crazy, healthy and ill, salve and free, father and son, wife and husband, rich and poor, scholar and ignorant, Muslim and atheist and so on", ${ }^{35}$ and on this basis, he has once again recalled the non-religious origin of the constitutionalists, saying that "the atheist tribe played a major role in this game of constitutionalism for escaping from the decrees of Muslims toward the apostates from Islam". ${ }^{36}$

Another article which has been seriously criticized in this treatise by Nouri from the viewpoint of Islamic jurisprudence is "the freedom of pen and freedom of press". In the viewpoint of Nouri that period was the time of presence of antiIslamic religious and political sects and currents or as he says "the atheist" sects, and he practically saw the existence of the article in the Amendment as a tool for free publication of anti-Islamic issues by bringing up numerous intellectual and jurisprudential arguments against the article. So, he implicitly considers the designers of the article as anti-Islamist who are seeking to achieve and carry out easier anti-Islamic approaches. Therefore, he clearly says, "all the nonsense is for destroying the basis of religion and Islamic Shariah... they hijacked the religion and did their best to destroy it, unless the spread of justice does not need such arrangements." 37

Another treatise, Sheikh Fazlollah Nouri has writing in criticizing and rejecting the constitutionalism, as mentioned in the beginning of the present discussion, is Tazkerat al-Qafel and Ershad al-Jahel. ${ }^{38}$ Nouri in this book first speaks about the

34. Nouri, The Treatise of Sanctity of Constitutionalism, 260.

35. Ibid, 265

36. Ibid, 266

37. Ibid, 268

38. A number of researchers have expressed doubt in the treatise's definite attribution to Sheikh Fazlollah Nouri, but they have not achieved an absolute result, see Zargarinejad, The Treatises of Constitutionalism, 277-279 
necessity of the existence of law in the society, stressing that the best divine laws has been set in Islam for worldly life due to importance of the existence of law. He concluded that the Muslims do not need to enact or fabricate law. So, he announced the issue of legislation against the Islamic Shariah, and wrote:

"So, the fabrication of law is totally against Islam and this is a prophetic job. Thus, that was why the prophets were selected by God. Some decrees were signed or changed by the prophets till the last Prophet (SAWA) was selected and he totally represented the religion of God. So, he is the last prophet and the divine law brought by him is completely perfect even toward all the periods and toward all the people... the result is that nobody should fabricate the law... so the assembly the people wanted to set up and to approve laws with the majority of the votes is against the prophecy and religion. ${ }^{139}$

Therefore, Nouri's statements clearly show that from his viewpoint in the position of a Mujtahid and a jurist, any new thinking even if its origin is ignored is against the Islamic Shariah. And it is merely on this basis that Nouri talks about being Islamic or non-Islamic of the laws of the constitutional system. In this line, he addresses the issue of equality and freedom, and in the book he also regards as against Islam these two principles the foundation of which is based on slavery, calling them "harmful". Finally, he concluded that the aim of constitutionalists from bringing up such principles unlike their claim has not certainly been to implement divine laws. ${ }^{40}$ Then, he refers to the issue of "freedom of pen and language", citing a long list of anti-Islamic statements by the supporters of constitutionalism in the newspapers and pulpits as clear evidence of the harms of un-trammeled freedom. Thus, like the treatise of the Sanctity of Constitutionalism, he considers the backing of non-Islamic sects from constitutionalism as a firm reason for the non-Islamic and anti-Islamic nature of the foundation of constitutionalism:

"If the aim was to boost Islam why all atheists from Bahia' to other corrupt people such as Jews, Indian idolaters and the entire atheist countries and all the world sects except a special group of believers wanted to strengthen it. Oh, my dears, if the aim was to boost Islam, the Britain would not support it and if their purpose was to follow the holy Quran, they would not deceive ordinary people, and take refuge to atheism and would not choose them as their collaborators [He meant the constitutionalists' sitin in the British Embassy]. Finally, which stupid man accepts that atheism backs Islam?" ${ }^{41}$

\section{Conclusion}

As it was seen, we can present an almost comprehensive and complete image of the jurisprudential bases of the theory from Nouri's viewpoint and the reasons

39. Nouri, Tazkerat al-Qafel and Ershad al-Jahel, 5-8.

40. Ibid, 9-10.

41. Ibid, $17-18$ 
and necessities of raising the theory by reviewing the related historical events and by bringing up Sheikh Fazlollah Nouri's Legitimate Constitutional Theory and referring to his main works. An image which has been less noticed by the researchers of the area especially the supporters of the constitutionalism due to their opposition or agreement with it. As it was discussed, although Nouri was aware of some interests of the constitutional system, he sought to criticize and reject the theoretical bases of the constitutional system and defend the bases of Islamic religion due to the presence and interference of non-Islamic and sometimes anti-Islamic groups, individuals and currents in the movement, and was ready to sacrifice his life because of his deep religious and Islamic beliefs. Nouri's standing on his belief even sacrificing his life shows clearly that more than anything else; he, in the position of religious authority and religious jurist, had been worried about protecting Islam against anti-Islamic attacks. This is the case which has been almost entirely ignored in the sources of pro-constitutionalists, and they have considered Nouri's defense of Islam as the result of his support for autocracy, while Nouri's presence in the current of constitutionalism and sacrificing of his life clearly shows that such analyses are not complete, and that Nouri's thought has been noticed less. Furthermore, the historical conditions of that period of Iranian society has been less paid attention by the opponents of Sheikh Fazlollah Nouri for understanding and analyzing his thinking; the conditions on the basis of which Nouri concluded that the structure of constitutionalism had defects which were not able to protect Iran's sovereignty and independence as an Islamic country. Thus, from his point of view, the constitutional system was against the basis of Islam.

\section{Bibliography}

Ajoodani, Mashallah. Iranian Constitutionalism. Akhtaran Publication, 2004.

Adamiyat, Fereydoon. The Thinking of Freedom and Start of Constitutional System. Sokhan Publication, 1961.

Adamiyat, Fereydoon. The Ideology of Constitutional Movement. Payam Publication, 1976.

Afary, Janet. The Iranian Constitutional Revolution (1906-1911), translated by Reza Rezaee. Bisotun Publication, 2000.

Etemad al-Saltanah, Mohammad Hassan Khan. Al-Ma'aser val-Asar, vol. 1, edited by Iraj Afshar. Asatir Publication, 1984.

Bamdad, Mehdi. The Profile of Iranian Statesmen in $12^{\text {th }}, 13^{\text {th }}$, and $14^{\text {th }}$ Hijri Centuries, vol. 3. Tehran: Zavvar Publication, 1968.

Bastani Parizi, Mohammad Ebrahim. Freedom Effort. Tehran: Nouvin, 1957.

Bahar, Malak al-Shoa'ra. A Brief History of Political Parties, vol. 1. Amirkabir Publication, 1982.

Bahmani, Javad. The Tragedy of Century or Executing Sheikh Fazlollah Nouri, the Most Senior Religious Figure of Tehran in Public. Tehran, 1980.

Boroujerdi, Mustafa. The First Acclaimer of Legitimacy in Constitutional Injustice. Tehran: n.d.

Dowlatabadi, Yahya. The Life of Yahya, vol. 2. Ferdowsi Publication, 1982. 
Hedayat Mehdi, Qoli. Memories and Risks. Zavvar Publication, 1982.

Kasravi, Ahmad. Iran's Constitutional History. Tehran Amirkabir Publication, 1994.

Kermani, Nazem al-Islam. The Awakening History of Iranians, 3 vols., edited by Ali Akbar Saeedi Sirjani. Bonyad-e Farhang-e Iran Publication, 1967-1970.

Kia, Tondar. The Secret of Gallows, an analytical report on the resultant of Ayatollah Sheikh Fazlollah Nouri's joining to the Constitutional Movement. Ketab-e Sobh Publication, 2002.

Malcolm, Napier. Five Years in a Persian Town. London: John Murray, 1907.

Malekzadeh, Mehdi. The History of Iranian Constitutional Revolution. Tehran: Elmi Publication, 1994.

Malekzadeh, Mehdi. The Life of Malek al- Motakallemin. Tehran: Elmi, 1946.

Mardoukh Kurdistani, Sheikh Mohammad. Mardoukh History. Tehran:Karang Publication, 2000.

Mostowfi, Mirza Nasrollah Khan. The History of Iranian Revolution, vol. 1. The manuscript of Malek Library, n.d.

Nouri, Sheikh Fazlollah. The Treatise of Tazkerat al-Qafel and Ershad al-Jahel. Stone Printing, n.d.

Nouri, Sheikh Fazlollah. "The Treatise of the Constitutional Sanctity." In Gholam Hussain Zargarinejad, The Treatises of Constitutionalism, vol. 1. Kavir Publication, 2008.

Rezvani, Homa. Agha Sheikh Fazlollah Nouri's Lavayeh. Jibi Publication, 1983.

Torkaman, Mohammad. Treatises, communiqués, written materials, ... and Sheikh Fazlollah Nouri's newspaper, vol. 1. Tehran: Ferdowsi Publication, 1983.

Yaqmaee, Iqbal. The Martyr of Freedom Path Seyed Jamal Va'ez Isfahani. Tous Publication, 1978.

Zargarinejad, Gholam Hussain. The Treatises of Constitutionalism, vol. 1. Tehran: Kavir Publication, 2008. 